\title{
Community engagement as the organic link with the street: Creating a learning community between the academy and homeless people in Tshwane
}

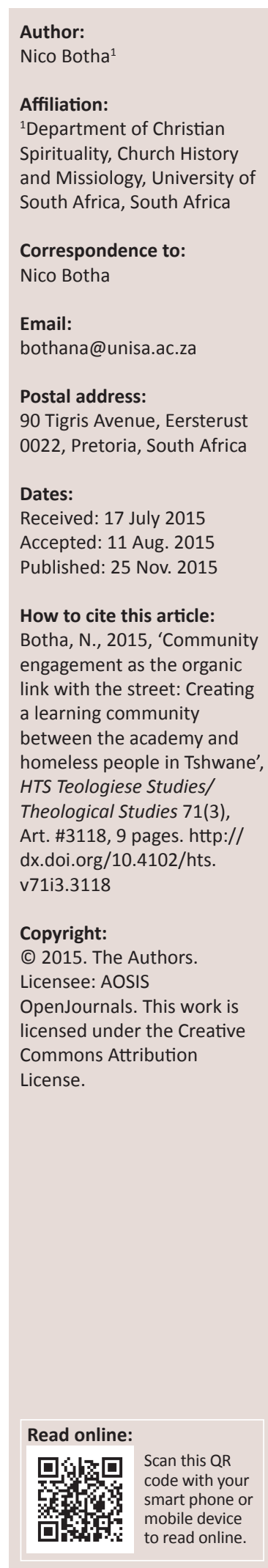

Does the current community engagement project, of the Department of Christian Spirituality, Church History and Missiology at the University of South Africa (UNISA), respond to the conceptual discourse on community engagement? Informed by this question this article's objective is two-pronged. Firstly, an attempt is made to locate the project's beginning in a proper historical perspective by engaging the initial ministry of the Department with homeless people. The narrative about the work of a Mennonite couple is told by structuring it around the dimensions of agency (identification or insertion), context analysis, strategies for mission and theological reflection or in simple terms, the reading of the Bible. Secondly, this article proceeds by subjecting both the initial ministry with homeless people and the community engagement project, in its current form, to the scrutiny of three high ranking publications from the Higher Education Quality Committee in collaboration with JET Education Services, the Council on Higher Education and a handbook on service learning in South Africa on the conceptual clarification of service learning and community engagement. As the documents reveal some difference of opinion amongst the experts, the bottom-line is that unless the interaction between the academy and the community (homeless people) is a consistent, sustainable, reciprocal and mutual process aimed at creating a genuine learning community, the project is called into question. A further issue is that the engagement between the parties must find reflection in what is taught - students or learners are to benefit from this - and researched.

\section{Introduction}

Academics at institutions of higher learning are strongly encouraged to participate in community engagement. As a matter of fact, community engagement is no longer optional, but like academic leadership, tuition (teaching and learning), research and academic citizenship, forms part of the key performance areas against which the performance of an academic is measured. For quite some time diverse forms of involvement in communities, or what is also known as community service, has been identified as community participation. For example, an academic theologian who is doing some preaching on Sundays would be viewed as being involved in good community participation. Likewise, a social worker who advises people in her spare time on grant applications would also be seen as involved in community participation. Even a civil engineer advising township people who are constructing a road somewhere constitutes a good example of community participation. There are numerous other examples, but these three suffice to arrive at the following question: Can any form of involvement in the community by academics, laudable as these efforts may be, necessarily be viewed as community engagement?

The University of South Africa (UNISA) Policy Document on Community Engagement contains the following definition:

Community engagement is defined as the scholarly activity of academic research and teaching that involves external communities and stakeholders in collaborative activities that address the socioeconomic imperatives of South Africa and the African continent while also enriching the teaching, learning and research objectives of the university. (The UNISA Policy Document on Community Engagement 2013:3)

Based on this definition the thesis of this article states that any 'donation of time and/or resources by UNISA employees ... to benefit a community' can only be regarded as community engagement if the organic link between the two is clearly demonstrated (2013:3). The term organic link is used to indicate the genuine reciprocity and collaboration between the academy and the community in creating knew knowledge.

An indispensable element to show the organic link between the academy, or more particularly the Department of Christian Spirituality, Church History and Missiology at UNISA, is the narrative 
on how the connection came about. As far as the community engagement project of the Department is concerned one can safely suggest that the ministry with homeless people in Tshwane was started by two Mennonites, the Beghelas from the DRC who helped the discipline of Missiology to see the link between a very particular theological method used and the real life situation of homeless people.

The method referred to is the pastoral or praxis cycle (Holland \& Henriot 1983). Others like Cochrane, De Gruchy and Petersen (1991), Faix (2003), Karecki (2005) and Kritzinger (2008) have added value to this cycle by rendering their own adaptations. The four steps suggested by Holland and Henriot are insertion, context analysis, theological reflection and planning. Much as one prefers to keep it simple, by staying with the four steps of the cycle as they originated with the two Jesuites, the term 'insertion' is slightly awkward as a metaphor borrowed from woodwork, suggesting an intense and seamless involvement in issues. Perhaps the term 'agency' as applied by Kritzinger or 'identification' as suggested by Karecki provides greater clarity on the matter, particularly if informed by questions like who are the actors? and How do they position themselves in and identify with a community? The other three steps as developed by Holland and Henriot do not throw up the same kind of awkwardness, although even as far as context analysis is concerned, Kritzinger chooses the term 'understanding' rather than 'analysis' when referring to the prevailing religious, economic, political, cultural and social circumstances. A further issue is that he substitutes theological reflection with Interpreting the tradition and includes both the reading of the Bible as well as our theological tradition and discernment for action rather than simply planning. This clarifies the issue, but results in unnecessary tautology as any reading of the Bible assumes underlying presuppositions and interpretive positions anyway. His proposal of substituting planning with discernment for action is indeed quite creative, but unnecessarily difficult for the categories of people in society who, by definition, would want to use cycle. The additions of reflexivity and spirituality appear to be didactically sound, but once again tautological as the cycle is, in terms of its four steps, if these are logically brought into critical discourse with one another, this act presupposes an important learning curve informed by the experiences of the agents in mission as well as their experience of God. Be that as it may, the following section of the article is aimed at narrating the manner in which the ministry of the Beghelas, amongst homeless people in the city of Tshwane, started by working through the four basic steps of the cycle.

\section{Agency}

The danger in identifying the agents in mission is that we can quite easily feed into the old paradigm of telling the story of the 'do-gooders', the benevolent, the missionary, and the charitable person, to name just a few. Much as the ministry described here was started by a particular family, the real agents of the mission became homeless people themselves. In the book titled Pavement encounters for justice. Doing transformative missiology with homeless people in the City of Tshwane (Kritzinger \& Mashau 2014), the active participation of homeless people in the Contextual Bible Study sessions is well recorded. Beghela (2012) relates two stories in showing that in the understanding of Freire (2000), homeless people are not mere empty containers to be filled or 'banks' - if such irony in the case of homeless people is permitted - where deposits are made. On the contrary, they have their own very unique and creative contributions to make, as examples below on the reading of the Bible show. Freire's notion finds a very creative appropriation with Roxburgh and Romanuk (2006) in their book on missional leadership. They write with reference to Freire:

He saw existing educational systems focused on what the professional educator knew rather than on the educator's ability to create a participatory community of learners where people discovered answers to the challenges they faced. For Freire the shift to this participatory model required educators who could create an environment where dialogue among people could flourish. The dialogue and participation Freire described involved people helping each other articulate their lived experiences and bring those experiences into dialogue with Scripture. (pp. 76-77)

The relevance of this for the encounter with homeless people from the side of the academy is virtually self-explanatory. The need is non-negotiable for participation and dialogue, sharing and articulating experiences, reciprocity and mutuality.

The question of agency or identification is about the choices we make and the values we espouse or, to use the concept of Holland and Henriot (1983), 'insertion anyway'. In the context of the article agency is not simply any kind of agency or choice. For Holland and Henriot (1983) the option is undertaken for the poor and for the initiators of a ministry with people on the streets of Tshwane, and the choice is made on behalf of the homeless. Consequently, the values embraced are compassion, justice seeking and peace building. For genuine community engagement to come about in the academy such choices and values need to be factored into the curriculum and can indeed be enriched and sharpened in the encounter with homeless people.

\section{Context analysis}

In their publication, mentioned above, Kritzinger and Mashau (2014) refer to the metaphor of pavement features strongly as a way of drawing attention to the hard life of those living on the streets of Tshwane and the difficulties they confront. In the narrative related by Beghela (2015) on the real life situation of the homeless with whom their ministry started, images of a bush, trees and bridges play an important role in reading the situation of homeless people. Whilst residing in a block of flats close to the University of South Africa, the Beghela family became aware of serious complaints about people sleeping in the bush opposite their block of flats or under bridges constructed in the area around Mandela Street in Tshwane, which is shielded by trees. Incidents recorded include the harassment suffered by the Beghela daughters, 
on three occasions, and a lady who lived in the area who was brutally assaulted at gunpoint when returning home and had her jewellery and cash stolen.

For a number of reasons these incidents are factored into the step of context analysis. Firstly, the harassing and mugging of people, in itself, reveals the desperate situation of homeless people, some of whom have to resort to crime in order to survive. Secondly, the narrative shows something of the rather dialectical and ambivalent nature of metaphors. The pavement, which is constructed for the comfort of pedestrians and cyclists, is the only space for survival for homeless people. Bushes and trees, which nature conservationists will protect, become 'hiding' places and a refuge for homeless people. Bridges constructed for the free flow of traffic become places of refuge for homeless people, and can thus equally be seen as a metaphor for a hard life.

In the further unfolding of the Beghela narrative no mention is made of the involvement of the community policing forum or bringing together a neighbourhood watch. In the true understanding of the mission in Christ's way, homeless people were encountered as fellow human beings and a ministry with them was launched, instead of observing them with irritation and fear, and trying to stay out of their way as much as possible.

\section{Strategic planning for mission}

In terms of the logic of Holland and Henriot (1983) the reading of the Bible precedes planning in the cycle. It is the typical action-reflection approach or the see-judge-act method. Yet, based on how the Beghela narrative on ministry with homeless people unfolds, it is slightly more logical to have the theological reflection preceded by planning. An important assumption might be coming to the fore here: that one can start with any of the steps or mix them up, provided that the inherent logic and the necessary critical and creative tension between the different steps are not neglected.

The main objective of the ministry with homeless people was to develop an understanding of mission as peace making or peace building. At a 'bosberaad' or lekgotla, held at a Catholic Retreat Centre called Ha Phororo from 01 to 02 September 2011, for the discipline of Missiology at UNISA, participants were afforded the opportunity to share with others their basic understanding of mission. One of the presentations was on adopting mission as peacemaking amongst homeless people. For a proper and honest historical perspective it is of paramount importance to note that between the people involved at the discipline summit, a diversity of small initiatives were undertaken to advance the ministry with homeless people.

A number of concrete steps followed like negotiation with pastor Tulenge, of the Wonders Church in Tshwane, to provide space for fellowship and worship services and Bible studies with homeless people. Members from the Quakers, such as Janneke Weideman, supported the ministry by sharing meals with homeless people as well as engaging with them in Bible study. A set pattern of fellowship and worship services started developing with meetings on Wednesdays, Saturdays and Sundays.

Not many homeless and street people flocked to these services, which initially consisted of the Beghela family and twelve homeless people who joined the fellowship on a regular basis.

A number of small initiatives culminated in a big banquet of fifty homeless people on 16 December 2011 at the Minnaar Street facility of the Tshwane Leadership Foundation. Some colleagues from the Department of Christian Spirituality, Church History and Missiology, such as Annalet van Schalkwyk and her husband, and also Humphrey Mogashoa and Elijah Baloyi participated in the event. In a real sense the banquet of December 2011 was a forerunner for what has now become known as the Meal of Peace (MOP). The very symbolic nature of the banquet is well captured by two elements. Firstly, 16 December has now been changed from 'Geloftedag' (Day of the Covenant) to Reconciliation Day. In the conversation, between the academics present and the homeless people, on reconciliation the consensus was that we have not taken huge strides since 1994 in our quest for genuine reconciliation. A further consensus seemed to have been that the slow pace of reconciliation was to be blamed on the fragmentation and division caused in the past as well as the endemic dichotomisation between justice and reconciliation. Secondly, and significantly, the banquet was hosted only nine days before Christmas. As a matter of course the nativity or story of the birth of Jesus Christ formed an important part of the conversation. Not in terms of a generalised recycling of the story, but with reference to the sad reality that there was no place in the inn for him. Furthermore that he escaped death by the skin of his teeth, migrating as a refugee with his parents to Egypt. A rather critical discourse ensued on how to navigate between the creative tension between the following two challenges: firstly, not conjuring up theological justification for romanticising the harsh reality of homelessness, but rather to interpret the incarnation as a theological grounding for Jesus' solidarity with and preferential option for homeless people. Secondly, further input from the academics present at the banquet focused on the empowerment of homeless people through training and skills development for them to develop a measure of self-reliance by ultimately finding jobs, however complex the situation may be. As a follow up to the banquet of 16 December 2011, five homeless people were invited to speak at the March 2012 annual congress of the Southern African Missiological Society at UNISA. The significance of their presence at the congress was that the theme under discussion centred on a missiological analysis of the South African reality from the perspective of empire.

\section{Reading the Bible}

An important element of the ministry was the reading of the Bible, as a forerunner of the Departmental decision to 
engage with homeless people in Tshwane as the core of our community engagement project on the basis of West's Contextual Bible Study (CBS). There are two conversations which have been well recorded. In a study of Romans 1:16, 'For I am not ashamed of this Good News about Christ. It is the power of God at work, saving everyone who believes - the Jew first and also the Gentiles', Nkhutole, a homeless person, responded in the following manner:

You see here, it is said 'Jews' first of all and then the Gentiles come later. This shows that not all of us are part of the message of salvation. This 'Good News' is revealed for the benefit of the 'Jews'. I think we as homeless people are excluded as you can see the 'Gentiles' come afterwards. (Beghela 2012:310-311)

Equally interesting is Nkhutole's perspective on the encounter between Jesus and the Canaanite woman in Matthew 15:21-28. Essentially, the encounter came about because the woman had heard of the healing power of Jesus which, in His mission, was a distinct way of dealing with the debilitating effects of empire. Her daughter was demon possessed and she trusted Jesus to bestow liberation and healing on her. Jesus did not seem to have responded initially. The disciples were equally unhelpful by sending her away. The woman persevered, however, with a simple plea: 'Lord help me please!' In Nkhutole's interpretation Jesus responded ultimately in a deceitful manner by denying the humanity and rights of this Gentile woman by suggesting 'I can't give the food for children to the dogs'. For Nkhutole the Bible was primarily written for and about the Jews. In his understanding these two stories feed into the voiceless-ness of homeless people.

Beghela's (2012) response to this kind of Bible interpretation is far from satisfactory and simply says:

However, such an explanation of the Bible is wrong. As we are all created in the image of God, and homeless people should not feel like second class citizens or less important anymore. (p. 311)

The response aggravates rather than alleviates the situation of homeless people in more than one respect. It shows a serious analytical shortcoming by unintentionally calling the imago Dei and the issue of citizenship into service, that is not at all helpful in arriving at a deeper understanding of homelessness.

\section{Community engagement as organic link: A conceptual exploration}

The response of Beghela to Nkhutole's deconstructionist interpretation of Scripture is perhaps the precise juncture where reflection on the meaning of community engagement is needed. The question which arises is: How does one avoid the following two extremes: a mere collusion with ideas and actions from homeless people and being bluntly dismissive of their contributions. Simply to call their interpretations of the Bible wrong, and to superficially appease them with reference to the imago Dei, does not constitute genuine community engagement where the parties involved learn from one another in a reciprocal process.
The discussion proceeds not by identifying, in clear terms, the best reading strategy, although many commentators might assist in responding to Nkhutole's interpretation in a more transformative and liberating fashion. Examples of such responses might include:

- an appropriation of the Contextual Bible Study or CBS (West 1993)

- a postcolonial biblical hermeneutic (Dube \& Staley 2002; Sugirtharajah 1998, 2003, 2012)

- a relational reading strategy (Horsley 2003).

To name only these few or the strategy of consciously avoiding particular portions from Scripture in dealing with the poor, women or homeless people, might help in arriving at a completely different understanding than simply dismissing Nkhutole's reading as wrong.

Instead of providing a piecemeal response, the discussion now turns to important conceptual issues relating to community engagement. Hall (2010:11) suggests quite strongly that the lack of conceptual clarity renders community engagement problematic at tertiary institutions. For him it comes down to simple questions such as: How does one define 'community' and 'engagement'? A pertinent question to be answered in the Department of Christian Spirituality, Church History and Missiology is: Does conducting a Contextual Bible Study with homeless people periodically in a very limited way, constitute community engagement? Conversely, this question arises even as far as the involvement with homeless people was concerned, in the narrative related in the article which reveals a more sustainable and consistent engagement with homeless people.

In concluding the narrative on the Beghela ministry with homeless people in the city of Tshwane the constitutive dimensions of the involvement are shown in pictures. The main thrust of the article is posing the critical question on whether or not even a ministry as genuine, consistent and sustainable as this could be seen as authentic community engagement; important images on the potential of such ministry to develop into a sustainable, conceptually sound community engagement project, are reflected. The pictures reveal the following dimensions: reading the Bible together, praying together, eating together, the non-racial side of homelessness and, sadly, also the utter despair and deprivation which are characteristic of homelessness (Figure 1).

\section{Towards a conceptual clarifying of community engagement: Focus on three high profile documents}

Based on the 1997 White Paper on Education the past decade has seen high profile documents appearing with specific reference to service learning and community engagement. Firstly, the 2006 publication on Service-Learning in the Curriculum: A resource of Higher Education Institutions and, secondly, Community Engagement in South African Higher Education, appearing in 2010. 

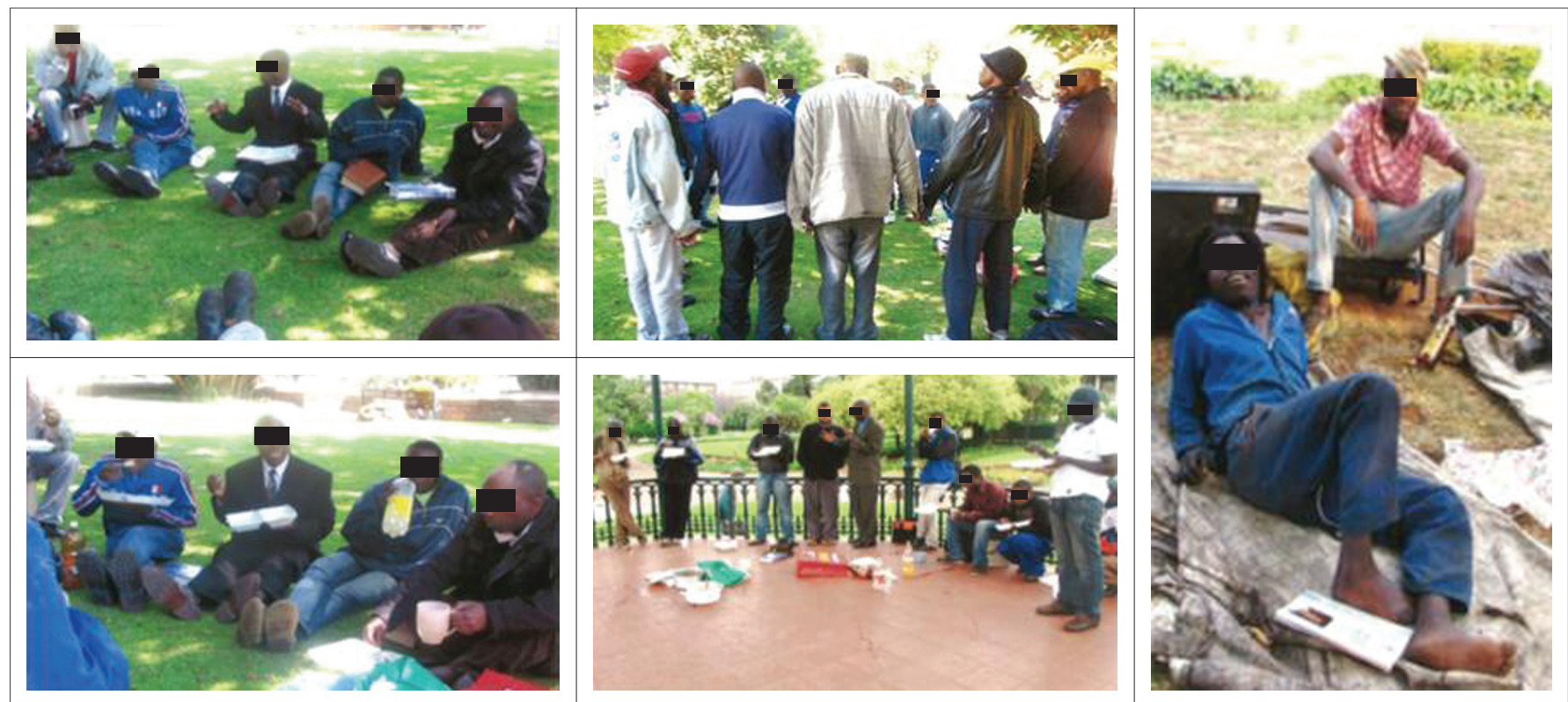

Photos provided by Ms P. Beghela

FIGURE 1: Images of the ministry with homeless people in Tshwane.

The rest of this article is aimed at seeing whether or not an engagement with the documents on a selective basis, for lack of space, assists in arriving at a clearer conceptual understanding of the current Departmental community engagement project.

All three documents are fairly rich in content, but a selection of issues most relevant for our own context will have to be made. As far as the first document is concerned the following are be the most important elements:

- the connection between service learning and community engagement

- different shapes of community engagement

- the indispensable nature of social transformation in community engagement

- the conceptual framework suggested.

\section{Community engagement and service learning}

There is no space nor any need to go back to the many different definitions arising over a period of time or the shifts that have occurred (HEQC/JET Education Services 2006). What is abundantly clear in the first publication is that community engagement comes in diverse forms as illustrated by the diagram titled Types of community engagement (HEQC / JET Education Services 2006:12) (Figure 2; my adaption).

Pleases note that there are errors in the publication. The correct version was published in the other HEQC/JET Education Trust publication: A good practice guide and selfevaluation instruments for managing the quality of servicelearning (June 2006:13).

One of the salient features of the diagram is its learner or student-centred nature. The diagram depicts the various

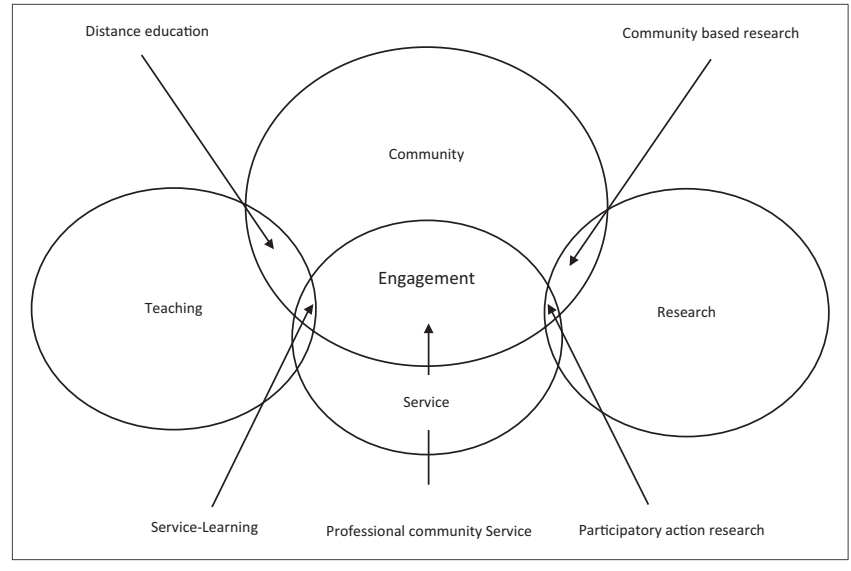

Source: Adapted from Higher Education Quality Committee/JET Education Service (HEQC/JET Education Services), 2006, Service-learning in the curriculum: A resource of higher education institutions, Council on Higher Education, Pretoria (Adapted from Bringle, Games \& Malloy 1999)

FIGURE 2: Types of community engagement.

forms of CE. Only the little nexus that is pointed out as Service-Learning is 'student-centred' as it indicates curricular CE. Professional Community Service might also be studentcentred if it refers to community service that forms part of the professional training of students. Much as the diagram is indeed also aimed at professional community service and on research in the mode of Participatory Action Research, it plunges the Departmental community engagement project in a serious crisis. It is currently carried by one major event called the Meal of Peace (MOP), limited contact between academics in the Department and homeless people, and research which is narrowly based on very limited Contextual Bible Study sessions with homeless people.

\section{Social transformation}

The publication draws from Dewey's (in HEQC/JET Education Services 2006:34) contention that 'education is 
linked to social reconstruction and is a primary means of social transformation'. In the interpretation of Salmarsh (in HEQC/JET Education Services 2006:43) 'Schools have a role in the production of social change'. The 2010 document highlights Dewey's notions of a 'connected view of learning, social problem solving and education for citizenship, which are cornerstones of service learning' (Eyler and Giles in HEQC/JET Education Services 2006:45). In the further evolvement of ideas from Dewey a major challenge, for the community engagement project of the Department of Christian Spirituality, Church History and Missiology, is whether or not the connection between study and service is indeed an illuminating experience and, conversely, whether experience lends energy and meaning to the discipline or not (HEQC/JET Education Services 2006:16).

In the case of the discipline of Missiology at UNISA the question is relevant for the existing as well as newly developed modules. This is asked concretely as a question rather than a statement: Is there any evidence yet in the curriculum that is intended to show how service learning is shedding light on the experience of students and how the experience amongst homeless people sheds light on the study material?

Yet another challenge for the Departmental community engagement project which has been dubbed Meal of Peace (MOP) is that it may be unintentionally aimed at harmonising the situation amongst homeless people, treating them to a fine banquet once a year and giving them exposure to the Bible without unequivocally working with them for social transformation. In the understanding of Pandor (in Hall 2010:26) there is a danger of such an approach resulting in a 'needy' definition of engagement with people. Although the prospect of working for transformation with homeless people is fraught with complexity. How does one join 'forces' with homeless people in working for transformation? This is where we shall have to turn to the curriculum to either have a distinct module on homeless people where different dimensions of the engagement could be factored in, or if this is rendered impossible at this stage of the re-curriculation of the BTh degree at UNISA, serious consideration should be given to working different dimensions of the community engagement project into the new modules. If the engagement with homeless people is aimed not only at alleviation, but social transformation, then the name given to the annual meal is questionable in itself. Something more apt might be Meal of Justice and Peace or Meal of Transformation and Peace.

\section{Conceptual framework}

The challenge for the current Departmental community engagement project is prolonged by the manner in which service learning is defined. The document that is being introduced here states:

Service-learning modules engage students in activities where both the community and student are primary beneficiaries and where the primary goals are to provide a service to the community and, equally, to enhance student learning through rendering this service. Reciprocity is therefore a central characteristic of servicelearning. The primary focus of programmes in this category is integrating community service with scholarly activity such as student learning, teaching, and research. This form of community engagement is underpinned by the assumption that service is enriched through scholarly activity and that scholarly activity, particularly student learning, is enriched through service to the community. Unlike the other categories of community engagement described above, service-learning is entrenched in a discourse that proposes the development and transformation of higher education in relation to community needs. Terms often used for this form of community engagement are 'service-learning', 'academic service learning', 'academic community service', and 'community-based learning'. (HEQC/ JET Education Services 2006:13-16)

Issues of scholarly activity feature strongly, but the emphasis is undeniably on 'student learning' which finds enrichment through service to the community. The transformation of higher education, in relation to community needs, can only really come about if the discourse is not confined to the ivory tower, but indeed becomes part of student-centred learning at tertiary institutions. This is, by definition, informed by the social, cultural, political and economic needs of the entire community. The key words in the above citation, shown in italics for obvious reasons, are paramount: the engagement in question here should first and foremost benefit the community and students, genuine learning should take place, and the process should be reciprocal. Judged merely in terms of these elements the Departmental community engagement project is falling short.

\section{Contested terrain: Is this a site of struggle?}

The complexity of defining community engagement or to stay for a moment with the concept of the document under discussion, service learning could be likened to attempts at defining globalisation, to mention one example. However, the document asserts that the definition which is 'commonly cited' comes from Bringle and Hatcher (in HEQC/JET Education Services 2006:127) who define service learning as 'a course based, credit-bearing educational experience'. They go on to show that such learning entails two basic dimensions, namely participation in an organised service activity meeting, identified community goals as well as reflection that results in further understanding of course content, amongst others. The notion that what happens in service learning should be integrated into an academic programme and curriculum is equally advanced in the HEQC list of definitions in its Criteria for Institutional Audits from 2004. There are a number of very clear indicators on how issues of the communities are understood that are involved in a partnership instead of being recipients. Partnership, in this context, relates to communities assisting in finding good definitions for issues contained in the relationship. These include the very understanding of service learning and the envisaged outcomes. Further issues are the identification of assets and the contribution to the mutual search for sustainable solutions. There is also a clear definition of 'communities' given in the context of 
the document under discussion: 'disadvantaged, materially poor inhabitants of under-serviced urban, peri-urban or rural areas' (HEQC/JET Education Services 2006:16). In borrowing from scholars such as Howard, Stacey, Rice and Langer this study defines the criteria for service learning as relevant and meaningful service with the community, enhanced academic learning, purposeful civic learning (social responsibility) and structured opportunities for reflection (HEQC/JET Education Services 2006:16)

The shortcomings of the current Departmental community engagement project are quite glaring when tested against these definitions and criteria. There is very little in the publication from 2014 which even remotely brings the project in line with the stated definitions and criteria. Although evidence is found in the 2014 book which gives insight into the Contextual Bible Study sessions conducted, there is nothing which is module-based or complying with the criteria identified. This does not, however, suggest that the ideas expressed in the document should be followed slavishly or that these are the only conceptual clarifications available, yet the current Departmental project is void of any conceptual clarification, except that a particular Bible study method is used. Once again, the problem could hardly be solved by individual academics having very limited contact with homeless people, once or twice a year for Bible study sessions of two hours, and then write articles based on such occasions. The shortcomings of the project will remain glaring, unless a solution is found in terms of a distinct module, or by factoring the community engagement project into existing modules grounded in thoroughgoing research emanating from regular interaction with homeless people where communities of mutual respect, learning and caring have been formed.

\section{From service learning to community engagement - Broadening the focus}

The 2006 document has consistently focused on service learning as a curricular form of community engagement, whereas the 2010 document has broadened the scope by focusing on the concept of community engagement. Reflections, by the different authors or contributors to the 2010 document, make it clear that the concept is neither selfevident nor self-explanatory. In the introduction to the 2010 document community engagement is very broadly defined as:

a cluster of activities that includes service learning, problembased teaching and research that addresses specific wants and needs, the pursuit of alternative forms of knowledge and challenges to established authorities that control and direct research systems and the allocation of qualifications. (HEQC/ JET Education Services 2006:7)

\section{Community and engagement}

The main contributor to the document, to whom others responded, pointed out that not even the terms 'community' and 'engagement' could be an understanding that is universally valid (Hall 2010). The difficulty in defining community, which might generally be seen as reasonably simple, is shown by Lange in her analysis of the HEQC's institutional audits. This, she argues,

is a vexed question as to what communities are, who they are and where they are. One of the questions we have asked of institutions in the audits (all of which have a de facto or de jure community attached to them) has been: 'Who is your community?' Some institutions defined their communities in historical terms, and remained stuck in the community divisions of the apartheid era. Some defined their communities in conservative terms, while others were more progressive. The question can be posed whether it is necessary to open or broaden the concept of community, since communities can be a form of democratisation, tolerance and pluralism. Does the community include those living on the doorstep of the institution or those further afield? The 'community' could be understood to mean everybody who is outside the institution (in other words, all stakeholders), including industry, the labour market, provincial and local government and NGOs. There are no clear answers to the question of who the community is. (Hall 2010:23)

Some helpful simplifications of the matter are made by Naidoo (in Hall 2010:23) who suggests a broader rather than a reductionist definition of community. The main thrust of his argument is that in different institutional entities different units may define community in a manner which fits them. In the case of the Department of Christian Spirituality, Church History and Missiology at Unisa community would be street and homeless people in the city of Tshwane in relation to their community engagement project. Naidoo is wary of having nice policies and structures in place or as he puts it, 'playing the community engagement game' without contributing to reconstruction and development in the country'. There are two important issues coming to the fore in the thoughts of Lange and Naidoo. Firstly, in Lange's definition there is solid argument on why the understanding of 'community' should not be taken for granted. Yet, there is also the danger of overkill in going to excessive lengths to satisfy the modernist need for a neat technical definition. Secondly, Naidoo's argument amounts to finding a working definition that can facilitate good solid community engagement, and nothing more.

The controversy sparked by how to understand community applies equally to the definition of 'engagement' in the 2010 document. The nature of the issue around defining 'engagement' is expressed as follows by Kaniki:

Claims to engagement by higher education institutions can be very broad, embracing almost any form of linkage: universities become involved in engagement with communities, sometimes without even having been invited by the communities ... How do you reconcile the view that universities can simply go into communities to offer help on issues that the universities believe they need, but of which they may not be aware? (in Hall 2010:24)

Instead of a rather general and broad definition the 2010 document suggests 'that engagement must be defined by some sort of partnership in which there is a mutual understanding of the objectives of specific projects'. Two models are called into service in the 2010 document in which processes 
are shown for establishing such partnerships. Reference is made to the notion of learning region (Favish 2010:89) and approaches advanced by the Asset Based Community Development. The latter states 'that communities have assets, the assessment of which by members of the community can be the basis for identifying needs and therefore the terms of productive partnerships' (De la Rey, August 2008 workshop in Hall 2010:24). Based on this, a pertinent query, to both the inaugural narrative on ministry amongst homeless people in this article and the current community engagement project, is whether needs were identified unilaterally or in genuine partnership. Do homeless people need praise and worship services, Bible study sessions and an annual meal of peace? This is not to be construed as a negative reflection, but as a serious academic question on the true nature of reciprocal engagement in its implications for teaching and learning in the mode of curriculum development. This relates to the critical point made in the 2010 document on how to reconcile the view that universities can simply go into communities to offer help on issues that the universities believe they need, but of which they may not be aware.

The 2010 document equally shows what can happen if the 'adjectival use' of the term community is problematised. It asserts:

... this use implies a generalised intention of doing good of bringing benefits from those in the university who have privileges to those outside who do not - it has the consequence of confirming that the relationship is unequal and therefore that the partnership - the engagement - is also unequal. (in Hall 2010:26)

\section{Hall's (2010:28) conceptual proposal of the 'third sector'}

Before introducing Hall's proposal there is an important disclaimer to be made. Any interaction with his extensive engagement on Community Engagement and the Construction of Knowledge (Hall 2010:9) is absent from this article. This does not mean that reflection of an epistemological nature is not relevant in a discussion on a conceptual clarification of community engagement. On the contrary, an important dimension of coming to grips with community engagement is to answer the question: How do we know what we know about any form of engagement between tertiary institutions and the community, irrespective of how 'community' is defined? Elsewhere in the 2010 document the point is made that community engagement is to be acknowledged as being 'a knowledge production activity to be accepted as a core key performance area at universities' (in Hall 2010:45).

Let us, however, turn to Hall's notion of the 'third sector' which he defines as follows:

An alternative approach, mooted tentatively here, would be to think instead of the critical third sector located between the family, the state and the market. This model recognises the key private benefits that higher education gives to individuals, empowering them for a world ever more demanding in personal skills and qualifications (benefits to the family). It also recognises the key role of universities in the private, market sector (innovation and knowledge transfer to industry, professional and vocational education), and also in enabling the work of the state (labour force development, public policy innovations, partnerships for enhancing service delivery. (Hall 2010:28)

Hall's idea of a 'third sector' comes under severe scrutiny by some critics in the 2010 document. The criticism raised by Nongxa (2010:56) is that in trying to address what he calls the 'definitional problem' associated with community engagement, Hall is not necessarily solving the problem by replacing 'community engagement' with another 'opaque concept that itself needs further definition'. It is, however, not clear at all if Nongxa's (2010:62) alternative provides us with a real solution: 'It seems to me that an easier and more elegant approach to making community engagement better understood is to build it into the notion of social responsiveness.'

Some of the reasons advanced by Nongxa (2010:63) for opting for a term such as social responsiveness are amongst others that it is accentuated in the 1997 White Paper on Education and in the 2001 National Plan for Higher Education as a national imperative. He also raises the issue of language in suggesting that social responsiveness is easy to understand. Further issues for Nongxa are that the terrain to all society is opened. The term social responsiveness also finds support from Favish, feeding into Hall's (2010) idea of public benefit which is defined in terms of

public goods ... conceptualised and offered in partnership with a range of external constituencies with the aim of contributing to generally accepted social and economic and cultural and environmental benefits as a form of return on the investment. (p. 89)

Is the concept 'social responsiveness' helping us to arrive at a clearer understanding of the issue under discussion? Is it not rather reinforcing the notion of merely showing the necessary responsibility to society in many different forms, without necessarily ensuring that in its engagement with the community the tertiary institution would learn from it in a reciprocal, mutual engagement. This will show in the curriculum and fitness for purpose or action research or any other form of research by scholars. Put differently, is social responsiveness not feeding into a linear process from the university to the community instead of a spiral or circular movement between the two? It has to be granted, however, that other than Nongxa, Favish (2010:89-95) shows examples from her institution in using the term social responsiveness that indeed there needs to be two-way traffic.

In his response to the debate on conceptualisation as far as community engagement is concerned, Slamat (2010:106) suggests that the issue is not about defining the concept from scratch. He rather looks at the changes the concept has undergone in scholarship. He proposes the notion of community engagement as scholarship. He states:

An alternative approach to start to define community engagement could be by referring to the notion of practices and their histories. 
Scholarship in a higher education context can be regarded as a practice with its own particular history and core activities. Historically the clear, uncontested core activities of scholarship in higher education are research and teaching. There might be ongoing debates about the methods and preferences in terms of research and teaching, but never about the status of research and teaching as core activities of the practice of scholarship in higher education. (Slamat 2010:106)

\section{Conclusion}

One of the main objectives of this article is to tell the story of how the community engagement project (Meal of Peace), of the department of Christian Spirituality, Church History, and Missiology started. As suggested at a Departmental meeting where the community engagement project was discussed in terms of a new round of publication, pertinent attention was drawn to the issue that it all started with the story narrated in the article. This laid the basis for what later emerged as a registered community engagement project of the College of Human Sciences of the University of South Africa. The story is structured around the praxis cycle to show in a type of 'uncut' fashion the elements of agency, context analysis, strategic action and the reading of the Bible. Controversies were thrown up by the reading of the Bible about how homeless people interpret specific portions from the text. An important decision had to be taken about whether or not to develop the article further by engaging diverse reading strategies mentioned in the article and, in so doing, to resolve the dilemma of dealing with very vulnerable people such as the homeless by not merely colluding with their understanding, nor simply dismissing them. Perhaps slightly arbitrarily it has been resolved that the more serious issue to investigate or at least to introduce hypothetically, in a sense, is an understanding of community engagement. The cursory and fragmentary discussion reveals that whichever way the concept is defined, the most indispensable issue is the mutuality and reciprocity between the academy and the community, whichever way community is defined. As far as the community project of the Department of Christian Spirituality, Church History and Missiology at UNISA is concerned, the challenge remains open of showing, in a convincing fashion, how the engagement with homeless people in the city of Tshwane contributes to a learning community where new knowledge is generated and the articulation is such that scholars could indeed be identified as 'organic intellectuals'.

\section{Acknowledgements Competing interests}

The author declares that he has no financial or personal relationships which may have inappropriately influenced him in writing this article.

\section{References}

Beghela, P., 2012, “'Rethinking African theology: Exploring the God who liberates' by Jean-Marc Ela", Studia Historia Ecclesiasticae 38(suppl. 1), 305-319.

Beghela, P., 2015, Qualitative interview on narrative of the street people in Pretoria, e-interview, 11 April 2015.

Cochrane, J.R., De Gruchy, J.W. \& Petersen, R., 1991, In word and deed: Towards a practical theology for social transformation, Cluster Publications, Pietermaritzburg.

Dube, M. \& Staley, J.L., 2002, John and postcolonialism. Travel, space and power, Sheffield Academic Press, London, New York, NY.

Faix, T., 2003, Der Empirisch-Theologosche Praxis-Zyklus als methodologischer Ansatz innerhalb der Missionswissenschaft, Unisa Press, Pretoria.

Favish, J., 2010, 'Towards developing a common discourse and a policy framework for social responsiveness', Kagisano, No. 6, Community Engagement in South African Higher Education, pp. 89-103, Council on Higher Education, Pretoria.

Freire, P., 2000, Pedagogy of the oppressed, 30th Anniversary edition, $30^{\text {th }}$ Anniversary edition, Bloomsbury Academic, New York, NY.

Hall, M., 2010, 'Community engagement in South African higher education', Kagisano, No. 6, Community Engagement in South African Higher Education, pp. 1-52, Council on Higher Education, Pretoria.

Higher Education Quality Committee/JET Education Service (HEQC/JET Education Services), 2006, Service-learning in the curriculum: A resource of higher education institutions, Council on Higher Education, Pretoria.

Holland, J. \& Henriot, P., 1983, Social analysis: Linking faith and justice, Orbis Books, Maryknoll, NY.

Horsley, R.A., 2003, Jesus and Empire. The Kingdom of God and the New World Disorder, Augsburg Fortress, Minneapolis, MN.

Karecki, M., 2005, 'Teaching missiology in context: Adaptations of the pastoral circle', in F. Wijsen, P. Henriot \& R. Meijsa (eds.), The pastoral circle revisited: A critical quest for truth and transformation, pp. 159-173, Pauline Publications, Nairobi.

Kritzinger, J.N.J., 2008, 'Faith to faith: Missiology as encounterology', Verbum et Ecclesia 29(3), 764-790. http://dx.doi.org/10.4102/ve.v29i3.31

Kritzinger, J.N.J. \& Mashau, D.T., 2014, Pavement encounters for justice. Doing transformative missiology with homeless people in the City of Tshwane, Acadsa, Parow.

Nongxa, L., 2010, 'An (engaged) response to Hall's paper: Community engagement in South African higher education', Kagisano, No. 6, Community Engagement in South African Higher Education, pp. 53-67, Council on Higher Education, Pretoria.

Roxburgh, A.J. \& Romanuk, F., 2006, The missional leader: Equipping your church to reach a changing world, Jossey-Bass, San Francisco, CA.

Slamat, J., 2010, 'Community engagement as scholarship: A response', Kagisano, No. 6. Community Engagement in South African Higher Education, pp. 53-67, Council on Higher Education, Pretoria.

Sugirtharajah, R.S., 1998, Asian biblical hermeneutics and postcolonialism, Contesting the interpretations, Academic Press, Sheffield.

Sugirtharajah, R.S., 2003, Postcolonial reconfigurations. An alternative way of reading the Bible and doing theology, SCM Press, London.

Sugirtharajah, R.S., 2012, Exploring postcolonial biblical criticism, history, method, practice, John Wiley and Sons Ltd., West Sussex.

The Unisa Policy Document on Community Engagement, 2013, pp. 1-11, viewed 15 July 2015, from https://staff.unisa.ac.za

West, G., 1993, Contextual Bible Study, Cluster Publications, Pietermaritzburg.

White Paper for Post-School Education and Training, 1997, Building an expanded, effective and integrated post-school system, Department of Higher Education And Training, Pretoria. 